\title{
ELECTRICAL CONDUCTIVITY AND SOYBEAN SEEDLING EMERGENCE
}

\author{
Julio Cesar Fachini Colete ${ }^{1}$; Roberval Daiton Vieira*; Alek Sandro Dutra² \\ ${ }^{1}$ Prefeitura Municipal - Secretaria da Educação, Rod. Rene Vaz de Almeida, km 4, 14770-000 - Colina, SP - \\ Brasil. \\ ${ }^{2}$ UNESP/FCAV - Depto. de Produção Vegetal, Via de Acesso Prof. Paulo Donato Castellane, s/n - 14884-900 - \\ Jaboticabal, SP - Brasil. \\ *Corresponding author <rdvieira@fcav.unesp.br>
}

ABSTRACT: Evaluation of soybean [Glycine max (L.) Merrill] seeds vigor and its relation with field seedling emergence can provide secure indicatives of seed physiological potential. The present research studied the relationship between the electrical conductivity test and the seedling emergence of soybean in field and laboratory. The field experiment was sown in November $26^{\text {th }}$, December $3^{\text {td }}$ and $10^{\text {th }}, 2000$. Laboratory tests were performed using levels of water potential in the substrate (soil) -0.03; -0.2; -0.4; and -0.6 MPa. Fourteen seed lots, seven of 'Embrapa 48' and seven of 'BRS 133' soybean cultivars were used. Laboratory tests comprised seed water content determination, before and after the accelerated aging; germination and vigor tests (accelerated aging and electrical conductivity). Germination and seedling emergence decreased as the substrate water potential was reduced, indicating a relationship among the germination, water potential and seed vigor. For the 'Embrapa 48' higher vigor seed lots, the best performance occurred at $-0.6 \mathrm{MPa}$ water potential. The electrical conductivity test may be efficient to evaluate soybean seed vigor and, consequently, the performance potential in the field. However, further studies are necessary to determine the values or the range of values that indicate the seed vigor level and the adequate use of a given seed lot.

Key words: Glycine max, seed analysis, water content, vigor, water potential

\section{CONDUTIVIDADE ELÉTRICA E A EMERGÊNCIA DE PLÂNTULAS DE SOJA}

RESUMO: A avaliação do vigor e sua relação com a emergência de plântulas em campo é fundamental para a estimativa correta do potencial fisiológico de sementes de soja [Glycine max (L.) Merrill]. O presente trabalho objetivou verificar a relação entre os resultados do teste de condutividade elétrica (CE) e os da emergência de plântulas de soja em campo e em laboratório. Foram estudados níveis de disponibilidade de água no substrato -0,03; -0,2; -0,4; e -0,6 MPa. Foram avaliados 14 lotes de sementes das cultivares Embrapa 48 e BRS 133. O experimento em campo foi conduzido em três épocas de semeadura (26/11 e 3 e 10/12/ 2000); em laboratório, foram determinados o teor de água, antes e após o envelhecimento acelerado (EA) das sementes, a germinação e o vigor (testes de EA e de CE). A redução progressiva da quantidade de água no substrato provocou diminuição das porcentagens de germinação e de emergência de plântulas em laboratório, de modo que o desempenho germinativo das sementes dependeu dos níveis de estresse hídrico e do vigor da semente. Para lotes de maior vigor da cultivar Embrapa 48, o melhor desempenho ocorreu sob o potencial hídrico de -0,6 MPa. CE pode ser um eficiente procedimento para a avaliação do potencial fisiológico e desempenho de lotes de sementes de soja, necessitando, porém, que estudos adicionais sejam conduzidos para o estabelecimento de valores ou limites de valores para caracterizar o nível de vigor das sementes (alto, médio ou baixo) permitindo direcionar de maneira consistente o uso dos lotes de sementes.

Palavras-chave: sementes, análise, vigor, teor de água, potencial hídrico

\section{INTRODUCTION}

Fast evaluation of seed physiological potential is an important tool for decision making in different stages of production process, storage and commercialization. Quality control evolves the seed germination and vigor evaluation.

Vigor tests based on the cellular membrane integrity are relevant because they make possible detection of initial phases of the seed deterioration process (Delouche \& Baskin, 1973). Therefore, technical measures can be taken to reduce or minimize the effect of deterioration and the consequent decrease in the seed physiological potential of a given seed lot (Dias \& Marcos Filho, 1996).

As much as seed vigor, substrate water potential is an active agent of the seedling establishment process in the field. According to Carvalho \& Nakagawa (2000), water is the main factor on seed germination. Water ab- 
sorption promotes tissue re-hydration with consequent intensification of respiration and other metabolic pathways, that supplies energy and necessary nutrients for triggering the growth of the embryonic axis.

Water availability is a basic factor to seed germination, and substrates should keep enough moisture to guarantee embryo growth. However, excess water reduces oxygen availability, and therefore respiration, delaying or paralyzing seedling development (Marcos Filho et al., 1987). Under water deficiency, seeds remain longer into the soil, therefore subjected to microorganisms attack (Carvalho \& Nakagawa, 2000).

This work aimed to study the relationship between electrical conductivity and seedling emergence tests under field and laboratory conditions.

\section{MATERIAL AND METHODS}

Trials were carried out in the laboratory and field experimental area, at Jaboticabal, State of São Paulo, Bra-

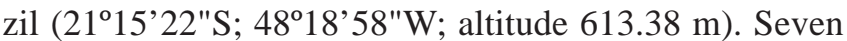
soybean seed lots of cultivar 'BRS 133' and seven of the 'Embrapa 48' were used. Preliminary evaluations of the seed physiological potential were performed through germination and vigor (electrical conductivity and accelerated aging) tests.

After the preliminary evaluations, and based on the electrical conductivity test, three seed lots of each cultivar were selected and classified as of low ( $>100$ and $<$ $\left.120 \mu \mathrm{S} \mathrm{cm}^{-1} \mathrm{~g}^{-1}\right)$, medium (81 - $\left.100 \mu \mathrm{S} \mathrm{cm}^{-1} \mathrm{~g}^{-1}\right)$ and high $\left(<80 \mu \mathrm{S} \mathrm{cm}^{-1} \mathrm{~g}^{-1}\right)$ vigor, respectively. This classification took into consideration reports of Vieira (1994), Vieira \& Krzyzanowski (1999) and Vieira et al. (1999a). The selected lots were used to study the relationship between the substrate water potential and seed germination and vigor, in laboratory experiments using soil with four water potentials: -0.03 ; $-0.2 ;-0.4$ and $-0.6 \mathrm{MPa}$.

Water content determination - Two 20-seed subsamples from each lot were weighed to the nearest 0.01 $\mathrm{g}$ and oven dried during $48 \mathrm{~h}$ at $105 \pm 3^{\circ} \mathrm{C}$ (ISTA, 1996). Water content was determined before and after accelerated aging tests, and results expressed in the wet basis.

Germination test - germination tests were performed with four 50-seed samples from each lot, in rolled papertowel previously moisturized with 2.5 times the paper weight. Germination proceeded in a germinator at $25^{\circ} \mathrm{C}$ and counts were made five and eight days after seeding (ISTA, 1996).

Accelerated aging test (AA) - Accelerated aging test was set using $42 \mathrm{~g}$ of seeds from each lot, distributed over an aluminum screen in germination plastic boxes $(11 \times 11$ $\times 3.5 \mathrm{~cm}$ ). The boxes received $40 \mathrm{~mL}$ of distilled water and were kept in a germination chamber (BDO type) for
48 hours (Hampton \& TeKrony, 1995; Marcos Filho, 1999). Seeds were then submitted to the germination test (ISTA, 1996).

Electrical conductivity test (EC) - Four 50-seed replications of each lot were weighed to the nearest $0.01 \mathrm{~g}$ and immersed in $75 \mathrm{~mL}$ of deionized water within 200$\mathrm{mL}$ plastic vials. Seed hydration occurred into a germinator at $25^{\circ} \mathrm{C}$, during 24 hours. After this period EC was determined in the imbibition's solution with a Digimed CD-21 constant electrode-1 conductivimeter, and results expressed as $\mu \mathrm{S} \mathrm{cm} \mathrm{g}^{-1}$ (Hampton \& TeKrony, 1995; Vieira \& Krzyzanowski, 1999).

Seedling emergence test (SE) - This field experiment was carried out in an experimental area of the Crop Production Department: 50-seed samples of each lot were manually distributed in $1.5 \mathrm{~m}$ long and $0.25 \mathrm{~m}$ apart rows at 2-3 cm depth. Sowing occurred in November 26th, and December 3rd and 10th. Emerged seedling evaluation was made 14 days after sowing (Nakagawa, 1999).

Seedling emergence under varying soil water potential - Soil substrate with varying quantities of water to provide potentials of $-0.03 ;-0.2 ;-0.4$ and $-0.6 \mathrm{MPa}$ were used. The water volume to give the correspondent water potential was determined from the soil characteristic water retention curve. An eutrophic Rhodic Hapludox was collected at 0 to $20 \mathrm{~cm}$ depth in an area adjacent to the field experiment. The soil was sieved for elimination of clods and stored in plastic boxes. Water content was determined in four 100 -g samples, oven-dried at $105 \pm 3^{0} \mathrm{C}$ for 24 hours. The seedling emergence evaluation was made with four 50 -seed replications each, seeded in plastic boxes $(28.5 \mathrm{~cm} \times 18.5 \mathrm{~cm} \times 10.0 \mathrm{~cm})$, with $3.5 \mathrm{~kg}$ of soil.

After the initial water content determination by the gravitational method (EMBRAPA, 1997), the quantity of water to be added to the boxes was estimated considering the soil water retention curve for attainment of the previously established potentials (Table 1). The soilwater mixture was homogenized, so that humidity was uniform in all the substrate volume. The plastic boxes were then covered with black polyethylene bags to prevent water evaporation. Twenty four hours later, germination boxes were filled with soil and sowing performed at a depth of $2 \mathrm{~cm}$.

The water volume to be added to each box (Table 1 ) was determined through the following equations:

$$
\mathrm{Q}=\theta_{\mathrm{c}}-\theta_{\mathrm{i}} \text { and } \mathrm{V}=[\mathrm{m}(\mathrm{Q} / 100)] / \mathrm{d}
$$

where: $\mathrm{Q}=$ amount of water to be added to the substrate (\%); $\theta_{c}=$ moisture in a volume base corresponding to the desired water potential (\%); $\theta_{\mathrm{i}}=$ initial soil moisture in a volume base (\%); $\mathrm{V}=$ volume of water $\left(\mathrm{cm}^{3}\right)$ to be added to each plastic box; $\mathrm{m}=$ soil weight $(\mathrm{g})$ in each plastic box; and $\mathrm{d}=$ soil apparent density $\left(\mathrm{kg} \mathrm{dm}^{-3}\right)$. 
Table 1 - Water volumes used to achieve the four water availability levels in the soil substrate.

\begin{tabular}{lcccc}
\hline Initial humidity & Water tension & Moisture degree in a volume basis & $\mathrm{H}_{2} \mathrm{O}$ to be added & $\mathrm{H}_{2} \mathrm{O}$ volume/ 3.5 kg soil \\
\hline$\%$ & $\mathrm{MPa}$ & $\mathrm{cm}^{3} 100 \mathrm{~cm}^{-3}$ & $\%$ & $\mathrm{~cm}^{3} \mathrm{~mL}^{-1}$ \\
\hline 2.4 & -0.03 & 22.0 & 19.6 & 527.7 \\
& -0.2 & 16.5 & 14.1 & 379.6 \\
& -0.4 & 14.8 & 12.4 & 333.8 \\
\hline 3.2 & -0.6 & 14.0 & 11.6 & 312.3 \\
\hline & -0.03 & 22.0 & 18.8 & 506.1 \\
& -0.2 & 16.5 & 13.3 & 358.1 \\
\hline 3.6 & -0.4 & 14.8 & 11.6 & 312.3 \\
& -0.6 & 14.0 & 10.8 & 290.7 \\
\hline 5.9 & -0.03 & 22.0 & 18.4 & 495.3 \\
& -0.2 & 16.5 & 12.9 & 347.3 \\
& -0.4 & 14.8 & 11.2 & 301.5 \\
& -0.6 & 14.0 & 10.4 & 280.0 \\
\hline & -0.03 & 22.0 & 16.1 & 433.5 \\
& -0.2 & 16.5 & 10.6 & 285.4 \\
\hline
\end{tabular}

After sowing, each box was wrapped in transparent polyethylene bags $(50 \mathrm{~cm} \times 80 \mathrm{~cm} \times 0.14 \mathrm{~mm})$ to prevent evaporation and possible alterations in the soil water potentials. The plastic bags were fixed in the box corners with the help of bamboo sticks and the bags ends were folded underneath the boxes. This germination apparatus was kept under room conditions $\left(25-30^{\circ} \mathrm{C}\right)$ without controlled temperature or air humidity.

Seedling emergence was evaluated ten days after sowing, when the considered emerged seedlings showed well characterized apparent plumule, cotyledon and hypocotyl over the soil surface. At that time, nongerminated seeds were rotten with fungi mycelia on their tegument.

\section{RESULTS AND DISCUSSION}

Initial seed water content varied from 10.9 to 11.5\% in 'Embrapa 48' cultivar (Table 2) and from 9.8 to $11.3 \%$ in 'BRS 133 ' cultivar (Table 3). Presenting similar water content values, is an important factor to run the accelerated aging and electric conductivity tests because results might be influenced by the seed initial water content (Hampton \& TeKrony, 1995; Vieira \& Krzyzanowski, 1999; Vieira et al., 2002). After the accelerated aging test and water content determination, it was observed compatible variation in the results, lower than 2 to $3 \%$, which are within the range considered adequate by several authors (AOSA, 1983; Hampton \& TeKrony, 1995; Marcos Filho, 1999; Vieira \& Krzyzanowski, 1999).

Initial seed germination, in all lots for the two cultivars, presented adequate values for commercializa- tion ( $\geq 80 \%$ ): 85 - 93\% for 'Embrapa 48' (Table 2) and 84 - 94\% for 'BRS 133' (Table 3). The cultivar 'Embrapa 48' (Table 2) was classified as of high vigor according to both tests (accelerated aging and electrical conductivity) (Egli \& TeKrony, 1995; 1996; Vieira, 1994; Marcos Filho, 1999; Vieira \& Krzyzanowski, 1999), once these authors compared several experiments. Vigor tests also shall present a relation with field seedling emergence (TeKrony, 1983; Marcos Filho, 1999).

Electrical conductivity tests allowed classification of seeds of both cultivars in two lots with different vigor levels. 'Embrapa 48' (Table 2) showed a variation from 71 to $83 \mu \mathrm{S} \mathrm{cm}^{-1} \mathrm{~g}^{-1}$ and 'BRS 133' (Table 3) from 75 to $98 \mu \mathrm{S} \mathrm{cm}^{-1} \mathrm{~g}^{-1}$. Soybean seed lots with EC within the limits of 60 to $70 \mu \mathrm{S} \mathrm{cm}^{-1} \mathrm{~g}^{-1}$ are considered of high vigor and between 70 to $80 \mu \mathrm{S} \mathrm{cm}^{-1} \mathrm{~g}^{-1}$ are considered of medium vigor (Vieira, 1994). In general, the higher the amount of ions released to the solution, the lower the germination, so ions release can be considered a measure of the physiological seed potential. Testing soybean seeds, Dias \& Marcos Filho (1996) found similar results. Seed lots with EC up to $100-110 \mu \mathrm{S} \mathrm{cm}^{-1} \mathrm{~g}^{-1}$ may present satisfactory field performance if environmental conditions are adequate (Paiva Aguero et al., 1997; Vieira et al., 1999a; 1999b).

Vigor tests have been used as complementary information to the germination test. They are considered efficient to classification of seed lots according to physiological potential, but it is also desirable that they provide coherent results with field seedling emergence.

The polynomial regression calculated for field seedling emergence (FSE) and electrical conductivity 
Table 2 - Seed water content values (SWC), standard germination test (SG), and seed vigor evaluated by the accelerated aging (AA) and electrical conductivity (EC) tests of seven soybean seed lots of ‘Embrapa 48’ cultivar.

\begin{tabular}{|c|c|c|c|c|c|}
\hline \multirow{2}{*}{ Seed lots } & \multicolumn{2}{|c|}{ SWC } & \multirow[t]{2}{*}{ SG } & \multicolumn{2}{|c|}{ Vigor } \\
\hline & Initial & After AA & & AA & EC \\
\hline & - & 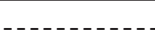 & 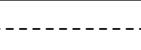 & - & $\mu S \mathrm{~cm}^{-1} \mathrm{~g}^{-1}$ \\
\hline 1 & 10.9 & 28.1 & $89 \mathrm{abc}$ & 87 a & $80 \mathrm{ab}$ \\
\hline 2 & 11.0 & 28.4 & $89 a b c$ & $84 \mathrm{ab}$ & 83 a \\
\hline 3 & 11.5 & 28.1 & 93 а & 90 a & $77 \mathrm{abc}$ \\
\hline 4 & 11.1 & 27.7 & $90 \mathrm{ab}$ & $86 a b$ & $76 \mathrm{bc}$ \\
\hline 5 & 11.0 & 27.7 & 92 a & $86 a b$ & $71 \mathrm{c}$ \\
\hline 6 & 11.2 & 28.0 & 86 bc & $84 a b$ & $82 \mathrm{ab}$ \\
\hline 7 & 11.3 & 27.5 & $85 \mathrm{c}$ & $81 \mathrm{~b}$ & 78 abc \\
\hline $\mathrm{F}$ test & & & $6.19 * *$ & $4.23 * *$ & $5.84 * *$ \\
\hline LSD by Tukey test $(\mathrm{d}=0.05)$ & & & 4.97 & 5.79 & 7.60 \\
\hline CV (\%) & & & 4.52 & 5.49 & 7.20 \\
\hline
\end{tabular}

*Means followed by the same letters in the column do not differ by Tukey test $(\alpha=0.05)$.

Table 3 - Seed water content values (SWC), standard germination (SG), and seed vigor evaluated by the accelerated aging (AA) and electrical conductivity (EC) tests of seven soybean seed lots of 'BRS 133' cultivar.

\begin{tabular}{|c|c|c|c|c|c|}
\hline \multirow[t]{2}{*}{ Seed lots } & \multicolumn{2}{|c|}{ SWC } & \multirow[t]{2}{*}{ SG } & \multicolumn{2}{|c|}{ Vigor } \\
\hline & Initial & After AA & & AA & EC \\
\hline & - & (n- & - & 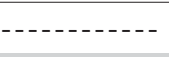 & $\mathrm{pS} \mathrm{cm} \mathrm{cm}^{-1}$ \\
\hline 1 & 9.9 & 23.1 & $89 \mathrm{abc}$ & $82 \mathrm{abc}$ & 79 c \\
\hline 2 & 10.1 & 25.1 & $87 \mathrm{bc}$ & $86 \mathrm{ab}$ & $84 \mathrm{bc}$ \\
\hline 3 & 9.8 & 24.6 & $85 \mathrm{c}$ & 79 bcd & $75 \mathrm{c}$ \\
\hline 4 & 10.9 & 24.8 & $84 \mathrm{c}$ & $73 \mathrm{~d}$ & $92 \mathrm{ab}$ \\
\hline 5 & 11.3 & 27.1 & 94 a & $77 \mathrm{~cd}$ & 98 a \\
\hline 6 & 10.1 & 24.3 & $89 \mathrm{abc}$ & 88 a & $75 \mathrm{c}$ \\
\hline 7 & 11.3 & 24.8 & $92 \mathrm{ab}$ & $83 \mathrm{abc}$ & 98 a \\
\hline F test & & & $7.70 * *$ & $9.57 * *$ & $15.87 * *$ \\
\hline LSD by Tukey test $(d=0.05)$ & & & 5.55 & 7.18 & 10.77 \\
\hline CV (\%) & & & 5.06 & 7.16 & 10.12 \\
\hline
\end{tabular}

*Means followed by the same letters in the columns do not differ by Tukey test $(\alpha=0.05)$.

(EC) for 'Embrapa 48' e 'BRS 133' cultivars are presented in Figures 1 and 2. Field seedling emergence increased as EC values decreased; this confirms results obtained by Vieira et al. (1999a) with soybeans. According to results of FSE and EC vigor tests, the seven seed lots of 'BRS 133' showed varying vigor, and in a lower scale than those observed for 'Embrapa 48'. Seed lot number 2 in the first sowing and seed lots 2, 6 and 7 from the second sowing (Table 4) of 'Embrapa 48' had a lower field seedling emergence than other seed lots. However no significant effects were observed.

Seed lots 4 and 5 from first and second sowing and seed lot 4 from third sowing of 'BRS 133' (Table 5) presented lower field seedling emergence than other seed lots. The relation between results of FSE and EC indicates that the latter can estimate with precision seedling performance in the field, depending upon prevailing en- vironmental conditions during sowing and seed lot vigor (Vieira et al., 1999a; 1999b).

Water availability affected seed germination in the varying soil water potential laboratory test. The observed variation was dependent on water stress and seed vigor (Figures 3 e 4). Best results were observed for 0.2 and $-0.4 \mathrm{MPa}$ and the worst for -0.03 and $-0.6 \mathrm{MPa}$, probably because of water excess or deficit, respectively. At the -0.2 and $-0.4 \mathrm{MPa}$ water potential both cultivars presented similar performance. High physiological potential (germination and vigor) of a given seed lot credentialed it for a superior performance in a broad range of field environmental conditions (Egli \& TeKrony, 1996; Marcos Filho, 1999).

The relationship between results of electrical conductivity tests and seedling emergence in the field and laboratory varied with water availability and seed vigor; 


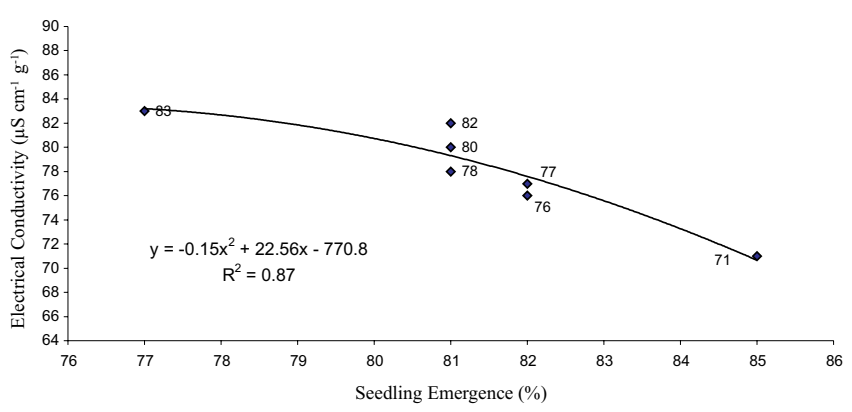

Figure 1 - Regression equation for the electrical conductivity test and field seedling emergence of the 'Embrapa 48' cultivar.

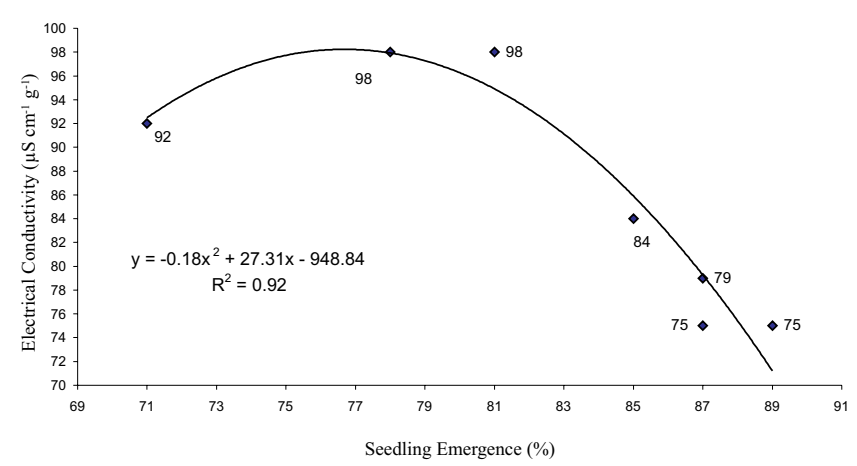

Figura 2 - Regression equation for the electrical conductivity test and field seedling emergence of the 'BRS 133' cultivar.

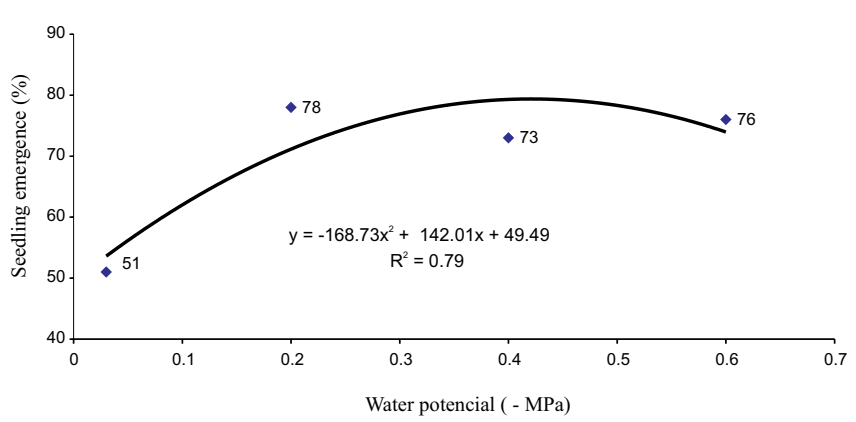

Figure 3 - Regression equation for the laboratory seedling emergence of seven seed lots of 'BRS 133'cultivar, under varied soil substrate water levels.

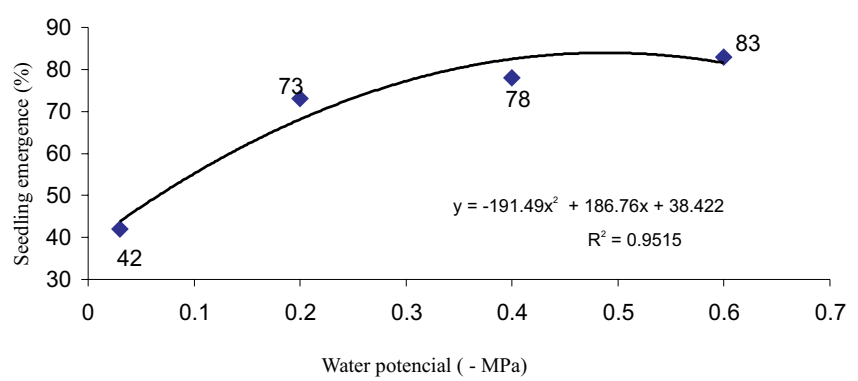

Figure 4 - Regression equation for the laboratory seedling emergence of seven seed lots of 'Embrapa 48'cultivar, under varied soil substrate water levels.
Table 4 - Field soybean seedling emergence of seeds originated from the seven lots of 'Embrapa 48' cultivar, in three different sowing dates ${ }^{1}$.

\begin{tabular}{|c|c|c|c|}
\hline \multirow{2}{*}{ Seed lots } & \multicolumn{3}{|c|}{ Sowing date ${ }^{2}$} \\
\hline & 1 & 2 & 3 \\
\hline & \multicolumn{3}{|c|}{ - } \\
\hline 1 & $81 \mathrm{ab}$ & 79 a & 82 a \\
\hline 2 & $74 \mathrm{~b}$ & 74 a & 83 a \\
\hline 3 & $84 \mathrm{ab}$ & 80 a & 83 a \\
\hline 4 & $82 \mathrm{ab}$ & 80 a & 83 a \\
\hline 5 & 86 a & 81 a & 89 a \\
\hline 6 & 84 a & $77 \mathrm{a}$ & 83 a \\
\hline 7 & 87 a & 74 a & 82 a \\
\hline F test & $3.64 *$ & $0.61^{\text {ns }}$ & $0.93^{\mathrm{ns}}$ \\
\hline LSD by Tukey test $(d=0.05)$ & 10.73 & 16.57 & 16.31 \\
\hline $\mathrm{CV}(\%)$ & 4.66 & 7.64 & 7.06 \\
\hline
\end{tabular}

${ }^{1}$ Means followed by the same letters in the columns do not differ by Tukey test $(\alpha=0.05)$.

${ }^{2}$ Sowing dates: 1 = Nov./26; 2 = Dec./3 and Dec./10.

Table 5 - Field soybean seedling emergence of seeds originated from the seven lots of 'BRS 133' cultivar, in three different sowing dates ${ }^{1}$.

\begin{tabular}{|c|c|c|c|}
\hline \multirow{2}{*}{ Seed lots } & \multicolumn{3}{|c|}{ Sowing date ${ }^{2}$} \\
\hline & 1 & 2 & 3 \\
\hline & \multicolumn{3}{|c|}{ - } \\
\hline 1 & 87 a & $85 \mathrm{ab}$ & 89 a \\
\hline 2 & $84 \mathrm{a}$ & $86 \mathrm{ab}$ & 86 a \\
\hline 3 & 90 a & $87 \mathrm{ab}$ & 84 a \\
\hline 4 & 72 a & $68 \mathrm{~b}$ & 74 a \\
\hline 5 & $77 \mathrm{a}$ & $71 \mathrm{ab}$ & 85 a \\
\hline 6 & 93 a & 88 а & 85 a \\
\hline 7 & 83 a & $76 \mathrm{ab}$ & 83 a \\
\hline F test & $2.81^{\mathrm{ns}}$ & $4.09 *$ & $2.05^{\mathrm{ns}}$ \\
\hline LSD by Tukey test $(\alpha=0.05)$ & 20.75 & 19.70 & 15.56 \\
\hline $\mathrm{CV}(\%)$ & 8.87 & 8.82 & 6.67 \\
\hline
\end{tabular}

${ }^{1}$ Means followed by the same letters in the columns do not differ by Tukey test $(\alpha=0.05)$.

${ }^{2}$ Sowing dates: 1 = Nov./26; 2 = Dec. $/ 3$ and 3 = Dec. $/ 10$.

seedling emergence in the laboratory varied with substrate water potential. The above results allow associating seed performance in the field and results of electrical conductivity tests, since environmental conditions might be simulated through variations in water availability.

Results herein reported confirm those obtained by Vieira et al. (1999a; 1999b) allowing a practical relation in the use of EC as a vigor test for soybean seeds. As a function of test results and seedling emergence relationships, inferences can be made upon seed performance potential and for what conditions a given seed lot might be recommended. 


\section{ACKNOWLEDGEMENTS}

To the 'COOPERATIVA AGRÍCOLA DA REGIÃO DE ORLANDIA' (CAROL) for the donation of seed lots and to CNPq for the scholarship.

\section{REFERENCES}

ASSOCIATION OF OFFICIAL SEED ANALYSTS - AOSA. Seed vigor testing handbook. East Leasing: AOSA, 1983. 93p. (Contribution, 32).

CARVALHO, N.M.; NAKAGAWA, J. Sementes: ciência, tecnologia e produção. 4.ed. Jaboticabal: Funep, 2000. 588p.

DELOUCHE, J.C.; BASKIN, C.C. Accelerated aging techniques for predicting the relative storability of seed lots. Seed Science and Technology, v.1, p.427-452, 1973.

DIAS, D.C.F.S.; MARCOS FILHO, J. Testes de condutividade elétrica para avaliação do vigor de sementes de soja (Glycine max (L.) Merril). Scientia Agricola, v.53, p.31-42, 1996.

EGLI, D.B.; TEKRONY, D.M. Soybean seed germination, vigor and field emergence. Seed Science and Technology, v.23, p.595-607, 1995.

EGLI, D.B.; TEKRONY, D.M. Seedbed conditions and prediction of field emergence of soybean seed. Journal of Production Agriculture, v.9, p.365-370, 1996.

EMPRESA BRASILEIRA DE PESQUISA AGROPECUARIA. Manual de métodos de análise de solos. 2.ed. Rio de Janeiro: EMBRAPA, CNPS, 1997. 212p. (Documentos, 1).

HAMPTON, J.G.; TEKRONY, D.M. Handbook of vigour test methods. Zurich: ISTA, 1995. 117p.

INTERNATIONAL SEED TESTING ASSOCIATION. International rules for seed testing. Seed Science and Technology, v.24, p.1-335, 1996. Supplement.

MARCOS FILHO, J. Testes de vigor: Importância e utilização. In: KRZYZANOWSKI, F.C.; VIEIRA, R.D.; FRANÇA NETO, J.B. (Ed.) Vigor de sementes: conceitos e testes. Londrina: ABRATES, 1999. cap.1, p.1-21.
MARCOS FILHO, J.; CÍCERO, S.M.; SILVA, W.R. Avaliação da qualidade fisiológica das sementes. Piracicaba: FEALQ, 1987. 230p.

NAKAGAWA, J. Testes de vigor baseados no desempenho das plântulas. In: KRZYZANOWSKI, F.C.; VIEIRA, R.D.; FRANÇA NETO, J.B. (Ed.) Vigor de sementes: conceitos e testes. Londrina: ABRATES, 1999. cap.2, p.1-24.

PAIVAAGUERO, J.A.; VIEIRA, R.D.; BITTENCOURT, S.R.M. Avaliação da qualidade fisiológica de sementes de cultivares de soja. Revista Brasileira de Sementes, v.19, p.225-260, 1997.

TEKRONY, D.M. Seed vigor testing - 1982. Journal of Seed Technology, v.8, p.55-60, 1983.

VIEIRA, R.D. Teste de condutividade elétrica. In: VIEIRA, R.D.; CARVALHO, N.M. Testes de vigor em sementes. Jaboticabal: FUNEP, 1994. p.103-132.

VIEIRA, R.D.; KRZYZANOWSKI, F.C. Teste de condutividade elétrica. In: KRZYZANOWSKI, F.C.; VIEIRA, R.D.; FRANÇA NETO, J.B. (Ed.) Vigor de sementes: conceitos e testes. Londrina: ABRATES, 1999. cap.4, p.1-26.

VIEIRA, R.D.; PAIVA AGUERO, J.A.; PERECIN, D. Electrical conductivity and field performance of soybean seeds. Seed Technology, v.21, p.15-24, 1999a.

VIEIRA, R.D.; PAIVA-AGUERO, J.A.; PERECIN, D.; BITTENCOURT, S.R.M. Correlation of electrical conductivity and other vigor tests with field emergence of soybean seedlings. Seed Science and Technology, v.27, p.67-75, 1999b.

VIEIRA, R.D.; PENARIOL, A.L.; PERECIN, D.; PANOBIANCO, M. Condutividade elétrica e teor de água inicial das sementes de soja. Pesquisa Agropecuária Brasileira, v.37, p.1333-1338, 2002.

Received April 24, 2003

Accepted April 23, 2004 